\title{
Turbulenciák Európa határán: a kelet-ukrajnai és transznisztriai konfliktusok
}

\section{Turbulences Bordering Europe: the Transnistrian and Eastern Ukrainian Conflicts}

Európa a 21. században viszonylagos békében élhetett - kontinentális értelemben véve az 1990-es évek balkáni háborúit, integrációs tekintetben pedig a II. világháborút követő idöszakban mindössze politikai, egyes esetekben gazdasági események következtében zajlottak kisebb-nagyobb megmozdulások. A térség keleti határán azonban található két egység, amelyek instabilitást jelentenek számára. Jelen tanulmány célja szaktanulmányok, az entitások nem hivatalos-hivatalos alkotmányai és idézójeles „állami” szervek oldalai, valamint az európai állami és integrációs nyilatkozatok, szervezeti határozatok és missziós jelentések segítségével a kelet-ukrajnai és transznisztriai, úgynevezett államtöredékek kialakulásának bemutatása, illetve jelenlegi rendszerük leírása mellett a földrajzi és nemzetközi szervezet értelmében vett Európa, valamint a tágabb értelemben vett nemzetközi közösség állásfoglalásának, kapcsolatrendszerének és problémamegoldó törekvéseinek vizsgálata.

A tanulmány előzetes feltevése, hogy a nemzetközi jog értelmében véve államnak nem tekinthető entitások státusz nélküliségükböl fakadóan nemzetközi kapcsolatok kiépítésére és fenntartására nem képesek, a nemzetközi béketeremtő törekvés következtében mégis kapcsolatfelvételröl beszélhetünk esetükben - e kapcsolat minöségi megitélésére a tanulmány végén a következtetések címszó alatt kerül sor a feldolgozott információk alapján.

Kulcsszavak: instabilitás, államtöredék, Donyecki Népköztársaság, Luhanszki Népköztársaság, Dnyeszter-menti Köztársaság

The $21^{\text {st }}$ century brought relative peace for Europe, but continentally only after the 1990s, following the Balkan wars. The mainly peaceful period after World War II was only interrupted by smaller economic or political disputes, however, there are

Szőke-Kis Bernadett doktorandusz, Szegedi Tudományegyetem Állam- és Jogtudományi Doktori Iskola, Szegedi Tudományegyetem Állam- és Jogtudományi Kar Nemzetközi és Regionális Tanulmányok Intézet, e-mail: bernadett.szokekis@irsi.u-szeged.hu 
two entities lingering on the Eastern part of the region that could possibly endanger the stability of said area. This study is based on further scholarly studies and legal documents such as constitutions (may they be recognised or not), official statements of states and international organisations, reports of international missions to the said entities and further information retrieved from official websites of governmental bodies; it aims to examine the roots of the conflicts of Transnistria and EasternUkraine and the ways of operation of the secessionist bodies, and finally reaches the question of the international reaction and actions towards them, including the continental issues and organisational ways of Europe. The study is built on the premise that these entities are not to be taken as a state according to international law and as such entities they do not bare the capabilities to build and have international relations - however, the peacebuilding and peacekeeping activity of the international community still bears some kind of contact between them, which are to be concluded at the end of this article.

Keywords: instability, secessionists, People's Republic of Donetsk, People's Republic of Luhansk, Republic of Transnistria

\section{Bevezetés}

A kelet-ukrajnai Donyecki Népköztársaság és Luhanszki Népköztársaság, valamint Transznisztria, más néven a Dnyeszter-menti Köztársaság a posztszovjet térségben található befagyott konfliktusok eredményeképpen kialakult úgynevezett államtöredékek. Mielőtt a tanulmány tartalmi részével foglalkoznánk, fontosnak tartom röviden tisztázni e két fő fogalmat, ezután az entitások bemutatását követően jelentőségüket tárgyalnám a földrajzi és politikai értelemben vett Európa felé, bemutatva annak szerepvállalását.

A posztszovjet térség mint földrajzi fogalom az egykori Szovjetunió felbomlását követően függetlenedett 15 állam által lefedett régiót jelenti. ${ }^{1}$ A 15 szuverén állam területén belül összesen hat vitatott státuszú entitás található, ezek az egységek Georg Jellinek munkássága után államtöredékeknek nevezhetők. Olyan egységek, amelyek az állam feltételeinek, tehát a terület, a népesség és a felettük gyakorolt főhatalom hármasának csupán részben felelnek meg - ezáltal nem teljes jogú államok, csupán annak töredékei. ${ }^{2}$ Ezek közül leginkább a már megnevezett ukrajnai népköztársaságok és a Moldova térségében található Transznisztria jelentenek fenyegetést az európai regionális stabilitás számára, így váltak jelen tanulmány témájává.

George R. Pittman: Why War? Indianapolis, Dog Ear Publishing, 2015. 218.

Georg Jellinek: Allgemeine Staatslehre. Berlin, Verlag von O. Häring, 1914. 394-434.

Európai Tükör 2020/3. 


\section{A konfliktusok kialakulása és kiteljesedése}

Mindhárom szakadár entitás, így mindkét állam, Ukrajna és Moldova esetében is a szeparatizmus közvetlen előzményeként foghatók fel a térségben lezajló gyakori és gyors nagyhatalmi változások a történelem folyamán. Az államiság ily módú változékonyságának hagyománya hozzájárulhatott a jelenlegi folyamatokhoz. Tekintve, hogy a transznisztriai események korábbra nyúlnak vissza, az időbeliség tiszteletben tartása miatt ezen entitás előzményeinek bemutatása következik, ezután kitérve az ukrajnai történésekre.

A mai Moldova térségében, az államot Ukrajnától elválasztó határ és a Dnyeszter folyómedre között húzódó entitás egykoriban a Basarab havasalföldi uralkodóról elnevezett, az I. világháborút követő időszakig Besszarábiaként ismert régióhoz tartozott. ${ }^{3}$ A hatéves orosz-török háború lezárását követően, 1812 után a Prut és Dnyeszter folyók között létrehozott entitás viszonylagos autonómiát élvezett a cári Oroszországon belül - azonban már ekkor megkezdődött a terület eloroszosítása, a moldáv lakosság asszimilációjával és az orosz nyelv és cirill írásmód dominanciájával. ${ }^{4} \mathrm{~A}$ két világháború között a nagyhatalmak által kötött békeszerződések, és -diktátumok többszörösen feldarabolták az említett egységet, több különböző fennhatóság alá besorolva azt. Végül a Szovjetunió területi terjeszkedése következtében egy főhatalom alá kerülve, 1940-ben a Moldáv Szovjet Szocialista Köztársaság entitásában egyesült a mai Moldova térségével. ${ }^{5}$

A Szovjetunió érája alatt a glasznoszty és peresztrojka nyitási eszméje enyhíti a politikai szigort, az ekkoriban kialakuló nemzeti mozgalmak vezetnek a szovjet integráció megrendülésével az 1980-as és 1990-es évek fordulóján a moldáv és transznisztriai térségek függetlenedési törekvéseihez. A két entitás között azonban már ekkor megfigyelhető feszültség, mivel az egykori szocialista köztársaságot ellátó ipari központok túlnyomó részben a Dnyeszter folyó keleti partján helyezkednek el - ezáltal a transznisztriai régió kiválása az akkori szocialista Moldáviából és a függetlenségre törekvő immáron Moldovából nemcsak területi veszteséget jelentene, de gazdaságilag is elfogadhatatlan. ${ }^{6}$ Miután Transznisztria 1990 augusztusában Pridnesztroviai Moldáv Köztársaság néven ${ }^{7}$ kikiáltja függetlenségét, Moldova akkori szovjet segítséggel katonai fellépéssel válaszolt, aminek következménye kétéves szembenállás a két egység között. ${ }^{8}$

Ezen a ponton fontos megállapítani, hogy a két entitás közötti konfliktus valójában egy területalapú vita - a Szovjetunió felbomlásakor mindkét entitás független

Nicholas Dima: From Moldavia to Moldova - The Soviet-Romanian Territorial Dispute. New York, Columbia University Press, 1991. 7-43.

4 Steven D. Roper: Regionalism in Moldova: The Case of Transnistria and Gagauzia. In James Hughes Gwendolyn Sasse (szerk.): Ethnicity and Territory in the Former Soviet Union: Regions in Conflict. London, Frank Cass, 2002. 102.

$5 \quad$ Hajdú-Moharos József: Fehéroroszország, Ukrajna, Moldávia. Budapest, ELTE Házinyomda, 1995. 155159.

$6 \quad$ Bruno Coppieters et alii: Europeanization and Conflict Resolution - Case Studies from the European Periphery. Gent, Academia Press, 2009. 149-180.

$7 \quad$ Frieder Monzer - Timo Ulrichs: Moldova - Mit Chisinau, ganz Bessarabien und Transdnestrien. Berlin, Trescher, 2016. 176-183.

8 Trevor Waters: Problems, Progress and Prospects in a Post-Soviet Borderland: The Republic of Moldova. IBRU Boundary and Security Bulletin, (1997), 1. 71-75.

Európai Tükör 2020/3. 
államként igyekezett elhagyni az egykori integrációt, azonban mindkét vitás fél magának követelte a moldáv-ukrán határ és a Dnyeszter folyó közötti sávot. Etnikai vagy vallási szembenállásról nem beszélhetünk, tekintve, hogy a két entitás lakossága jellemzően heterogén és hasonló csoportok alkotják. Transznisztria esetében a lakosságot moldáv, orosz és ukrán nemzetiségű polgárok alkotják, akiket a közös transznisztriai állampolgárság, valamint az orosz államnyelv kovácsol nemzetté. A moldáv (és ukrán, bár a Moldáv Köztársaság számára ez nem releváns) kisebbség elnyomásaként fogható fel esetleg az orosz államnyelv mellett a kisebbségi nyelvek tilalma például az oktatásban, de ezek a rendelkezések már a 2000-res évekre tehetők, tehát az 1990-es évek elején kirobbant konfliktushoz nem köthetők. ${ }^{9}$

1990 és 1991 során a transznisztriai egységek folyamatos összecsapások eredményeképpen egyre növelték az ellenőrzésük alá vont terület kiterjedését. Ennek eredményeképpen Moldovában 1991-re válsághelyzetet rendelt el a regnáló kormány. ${ }^{10}$ Miután az orosz és ukrán mediálással a háborús felek között zajló miniszteri szintű tárgyalás sem vezetett eredményre, további segítségnyújtás igénye jelenik meg belső és külső jelleggel. A Független Államok Közössége 1992-ben deklarálja békefenntartó misszióját, amihez bolgár és román csapatok is csatlakoznának - a misszió azonban nem valósult meg. ${ }^{11}$ Felismerve a segítség szükségességét, még ez évben Moldova az Európai Biztonsági és Együttműködési Szervezethez (EBESZ) fordulva egy speciális misszió felállítására kéri azt, amit azonban ekkor még szintén nem küldtek ki. ${ }^{12}$

Végül, a fegyveres összecsapások végét és a tárgyalások kezdetét a Sznegur moldáv, és Jelcin orosz elnökök közbenjárásával létrejött egyezmény hozza el. A dokumentum azonnali tűzszünetet eredményezett, és békefenntartó jelleggel orosz erőkkel egészíti ki a térség moldáv és transznisztriai katonai jelenlétét. ${ }^{13}$

Szemben a transznisztriai esettel, nem tudjuk a népköztársaságok kikiáltását egy pontból eredeztetni. Hasonlóan azonban a moldovai térséghez, a mai Ukrajna területe is évezredeken keresztül formálódott más-más nagyhatalmak uralma alatt, nem hagyva maga után stabil államiságot, hatalmat vagy egységet. Az ukrajnai entitások esetében a történelmi változások a térség megosztottságát eredményezték, így a jelen konfliktus közvetett előzményeként foghatók fel.

A térség első állama az északról a Volga folyón lehajózó Rurik varég viking dinasztia által 882-ben létrehozott Kijevi Rusz - Kijevi Fejedelemség, ami a Volgától Moszkváig és Szentpétervárig húzódó területen egészen az 1300-as évekig állt fenn. Az 1500-as évekre a központi hatalom gyengülésével a megnevezett területen kisebb fejedelemségek alakulnak ki, és vonják ki magukat a Rusz irányítása alól. ${ }^{14} \mathrm{~A}$ Kijevi Rusz bukásából

9 Gregorio Comai - Bernardo Venturi: Language and education laws in multi-ethnic de facto states: the cases of Abkhazia and Transnistria. Nationalities Papers, 43. (2015), 6. 886-905. 886-888.

10 Monika Heinzt (szerk.): Weak State, Uncertain Citizenship: Moldova. Frankfurt am Main, Peter Lang Verlag, 2008. 55-71.

11 Natalie Belitser (szerk.): Trilateral Plan for Solving the Transnistrian Issue. Bucharest-Chisinau-Kijev, Foundation for Open Society, 2006. 5-6.

12 First proposal on a special status for Transdniestria, considered a basis for the negotiating process. OSCE, 1993.

13 Agreement on the Principles for a Peaceful Settlement of the Armed Conflict in the Dniester Region of the Republic of Moldova 1992.

14 Font Márta: A Kijevi Rusz létrejöttének körülménye. História, 21. (1999), 9-10. 41-44. 
felemelkedő Moszkvai Fejedelemséggel párhuzamosan a régióban a 15. században Kozák-Ukrajna - Zaporizzsjai Szics katonai állama múködött. A Ruszhoz hasonlóan azonban néhány centenáriumon átívelő létezését követően 1638-ban IV. Iván orosz cárságába olvadt. ${ }^{15}$ A Kozák-Ukrajna orosz cári fennhatóság alá kerülését követően azonban egészen a 17. századtól a 20. századig, Ukrajna 1991-es függetlenedéséig a Szovjetunió alól az önálló ukrán államiság ideiglenesen más hatalom irányítása alá került. ${ }^{16} \mathrm{~A}$ mai Ukrajna területi kiterjedésének diverzifikációja a 16. században a Moszkvai Fejedelemség térnyerésével kezdődött, ekkor a nyugati régió már jellemzően keleti szláv identitású volt, míg a fejedelemség által erősödött nyugaton az orosz befolyás. A kozák államiság tekinthető a térségben az első ukrán etnikai alapú egységnek, ám ezzel párhuzamosan a mai ukrán területi kiterjedés nyugati térsége már az Orosz Birodalom befolyása alatt állt. Hasonló kelet-nyugati felosztottság jellemzi a 19. századot is a térségben, az osztrák és orosz birodalmak közötti felosztottságban. ${ }^{17}$

Az eltérő történelmi behatásoknak, valamint a Szovjetunió időszaka alatt egyrészt az orosz nyelv dominanciájának, illetve az önkéntes és központi népmozgásnak, népmozgatásnak eredményeképpen a függetlenedő Ukrajna etnikai, nyelvi és vallási tekintetben is megosztott. A 2001-es népszámlálás szerint lakosságának 77,8\%-a ukrán, míg további 17,3\% orosz nemzetiségú. Az államnyelv ugyan az ukrán nyelv, de egy 2012-es nyelvtörvény megnevezi az oroszt mint kisebbségi nyelvet és engedélyezi annak használatát az alapvető oktatásban azon térségekben, ahol a kisebbség többségi lakosságot alkot. A vallási megosztottság a keleti ortodoxián belül a Kijevi és a Moszkvai Patriarchátus közötti megoszlást jelenti. ${ }^{18}$ Nemcsak az etnikai alapú eltérés, de a nyelvi és vallási alapú különbségek is területi alapon mutatkoznak meg a mai Ukrajna területén kelet-nyugati szembenállást eredményezve, ami a későbbiekben a politikai állásfoglalás eltérésével is kiegészül. ${ }^{19}$

Ukrajna hivatalosan ugyan függetlenedett 1991-ben, de valódi rendszerváltás nem zajlott le közvetlenül a szovjet integrációból kiválását követően. A politikai életet továbbra is áthatja a korrupció, valódi személycsere sem történik a politikai elitben ${ }^{20}$ és a gazdaság átalakulása is lassú és nehéz folyamat - az életszínvonal nemhogy növekedne, csökkenni kezd, és az ipari termelés is recesszióba fordult. ${ }^{21}$ A lassú és szaggatott fejlődésben újabb törést eredményez a 2004-es úgynevezett narancsos forradalom. A háromfordulós választások választási csalásainak visszásságai és a tetőző korrupció csak további társadalmi elégedetlenséghez vezet. Igaz, hogy Viktor Juscsenko győzelmét követően demokratizálódás folyamata indult, például az alkotmány, de akár a hadsereg

\footnotetext{
15 Arday Lajos: Ukrajna - történelem, etnikum, identitás. International Relations Quarterly, 5. (2014), 1. 1-7.

16 Font Márta - Varga Beáta: Ukrajna története. Szeged, JATEPress, 2013. 223-225.

17 Karácsonyi Dávid et alii: East-West dichotomy and political conflict in Ukraine - Was Huntington right? Hungarian Geographical Bulletin, 63. (2014), 2. 99-134. 104-108.

18 Lubomyr A. Hajda: Ukraine. Encyclopaedia Britannica, 2020.

19 Yevhen Matviyishyn - Tomasz Michalski: Language Differentiation of Ukraine's Population. Journal of Nationalism, Memory \& Language Politics, 11. (2017), 2. 181-197. 181-182.

20 Taras Kuzio (szerk.): Contemporary Ukraine - Dinamics of Post-Soviet Transformation. Michigan, M.E. Sharpe, 1998. 48-117.

21 Font-Varga (2013) i. m.
} 
vagy a média reformjaival, ${ }^{22}$ a külpolitikai beállítottsága azonban a kelet-ukrajnai válság közvetlen előzményéhez vezetett, kiegészítve az eltérő történelmi hagyományokkal rendelkező és identitásbeli különbségeket mutató területek közötti, már fennálló feszültséget.

Viktor Juscsenko hatalomra kerülését követően a főként integrációs értelemben vett Európához közeledés az ukrán külpolitika központi elemévé válik. A kelet-európai, gyakran a Kelet és Nyugat között egyfajta átmeneti vagy összekötő szereppel ellátott Ukrajna Juscsenko ukrán elnök vezetésével tárgyalássorozatot folytat a társulásról az Európai Unióhoz. A 2010-es választásokon Viktor Juscsenko azonban alulmaradt Viktor Janukoviccsal szemben - ami kardinális jelentőséggel bír a 2010-es évek kelet-ukrajnai eseményeinek szempontjából. Janukovics ugyanis 180 fokos fordulatot adva az ukrán nemzetközi állásfoglalásnak a keleti közeledés politikáját indítja útnak. A 2013-ra a vilniusi európai uniós csúcstalálkozón már csak aláírásra váró társulás és Ukrajna nyugati integrációja drasztikus hirtelenséggel semmivé lett. ${ }^{23}$

A bemutatott folyamat eredményeképpen a 2010-es évek elejére Ukrajna geopolitikai tekintetben légüres térben lebeg a nyugati Európai Unió és az orosz dominanciával létrejövő Eurázsiai Unió integrációi között. ${ }^{24}$ A társadalmi elégedetlenség és a politikai alapú szembenállás egyre élesebb ellentétekhez vezet, ami 2013 novemberére tüntetésekben testesül meg. Az Európa-párti mozgalom tüntetéseinek fő helyszínéről, a kijevi Majdan térről a nyugati irányt támogató irányzat az Euromajdan nevet kapja. ${ }^{25}$

Az események 2013 végén, 2014 tavaszán a föváros térségében és a kelet-ukrajnai régióban szinte párhuzamosan durvulnak el. A Majdanon tüntetőkkel szemben a kormány katonai csapatokkal, fegyveres erőszakkal lép fel. ${ }^{26}$ Ezzel párhuzamosan a keleti politikai irányt támogató kelet-ukrajnai régió is megmozdul. 2014 májusától szeparatista erők szintén fegyveres fellépéssel vonnak területeket ellenőrzésük alá a Donyeckmedencében. A szeparatizmus intézményesüléseként elsőként a Donyecki Népköztársaság létrejöttét kiáltják ki április 7-én, ezt követi a szomszédos közigazgatási egység leválasztása a központi hatalom ellenőrzése alól, aminek függetlenedését Luhanszki Népköztársaságként április 27-én jelentik be. ${ }^{27}$

Az ukrán kormány megpróbálja katonai fellépéssel újra irányítása alá vonni a szeparatisták által leválasztott területet, sikertelenül. ${ }^{28} \mathrm{~A}$ fegyverszünet és a békekötés folyamata kizárólag nemzetközi közbenjárással tárgyalható, ennek bemutatását a transznisztriai tárgyalássorozat leírásával egyetemben a tanulmány következő fejezetében tárgyaljuk.

22 Juliane Besters-Dilger (szerk.): Ukraine on Its Way to Europe - Interim Results of the Prange Revolution. Frankfurt am Main, Peter Lang, 2009. 15-25.

23 Reinhard Hildebrandt: Die Ukraine - Grenzland oder Brücke? Reflexionen zum aktuellen Konflikt. Frankfurt am Main, Peter Lang, 2015. 26-35.

24 Elisabeth A. Wood et alii: Roots of Russia's War in Ukraine. New York, Columbia Univesity Press, 2015. 51-56.

25 Igari Léna: Vérontás: Ukrajna a polgárháború szélén. Hetek, 18. (2014), 8. 3.

26 Hildebrandt (2015) i. m. 35.

27 Richard Sakwa: Háború a határon. Budapest, Európa, 2016. 241-245.

28 Andrew Wilson: Ukraine Crisis - What it means for the West. New Haven - London, Yale University Press, 2014. 67-85. 


\section{A békekötés folyamata és a megszilárduló rendszerek}

Transznisztria esetében, a fegyverszünet megkötésétől hosszú és döcögős út vezetett a valódi békekötésig. 1992-től 2005-ig, 13 év alatt összesen tíz dokumentum, egyezmény, terv, találkozó valósult meg, amelyek mindegyike nemzetközi közbenjárással történhetett egy-egy kilengést követően a vitás felek kapcsolatának normalizálására.

A hosszú távú béke kiépítése érdekében a vitás felek közötti első közvetlen találkozó orosz mediálással Moszkvában zajlott 1997-ben. Az itt kidolgozott Moszkvai Memorandum az orosz közreműködés mellett nemcsak a Független Államok Közössége, de Ukrajna támogatásával jöhetett létre. ${ }^{29} \mathrm{Az}$ ukrán jelenlét a tárgyalássorozatban megkérdőjelezhetetlenné válik, amikor a további találkozót immáron Odesszában rendezik meg a rákövetkező évben. Az Odesszai Egyezmény a béke célkitűzése mellett a fegyveres erők leépítését és közös fejlesztési programokat helyez előtérbe. ${ }^{30} 1999$-ben, immáron Kijevben összeülő felek továbbra is a megjelölt hármak támogatása mellett szándéknyilatkozatot tesznek a közöttük fennálló feszültség feloldására. ${ }^{31}$

A 2000-es évek eleje azonban kiemelten moldáv részről föderációs törekvések erősödését hozza magával, aminek eredményeképpen az eddigi tárgyalássorozat megszakad. A 2002-ben, ismételten orosz és ukrán közbenjárással kidolgozott Moszkvai Protokoll a föderáció elvetésére sem javítja a felek romló kapcsolatát, ${ }^{32}$ ahogy a 2003-as Kozák Memorandum és az abban javasolt aszimmetrikus föderáció létrehozására törekvés sem nyeri el a transznisztriai térség jóindulatát. ${ }^{33}$

A romló viszonyok eredménye, hogy a 2005-ben az akkori ukrán elnök által kidolgozott úgynevezett Juscsenko-terv értelmében, ami javasolja önálló transznisztriai rendszer kiépítését, ${ }^{34}$ a régióban 2006-ban megtartják az első választásokat és stabilizálják önálló berendezkedésüket. ${ }^{35}$ A 2005-2006-os események eredménye Transznisztria jelenleg is múködő közigazgatása, amit röviden a következőkben tárgyalok.

The Moscow Memorandum - Memorandum On the Bases for Normalization of Relations Between the Republic of Moldova and Transdneistria. OSCE, 1997.

30 Odessa Agreement - Agreement on Confidence Measures and Development of Contacts between Republic of Moldova and Transdniestria. 1998.

31 Joint Statement of Participants in the Kiev Meeting on Issues of Normalisation of Relations between the Republic of Moldova and Transdniestria. 1999.

32 Stefan Troebst: The "Transdniestrian Moldovan Republic": From Conflict-Driven StateBuilding to State-Driven Nation-Building. European Yearbook of Minority Issues, 2. (2002), 1. 5-30.

33 Florentina Harbo: Can Federalism Cope with the Challenges of the Transnistrian Conflict? In Monica Heintz (szerk.): Weak State, Uncertain Citizenship: Moldova. Frankfurt am Main, Peter Lang, 2008. 185188.

34 Vladimir Socor: Poroshenko Drafts, Yushchenko Launches A Plan For Transnistria. Eurasia Daily Monitor, 2. (2005), 82.

35 William H. Hill: The OSCE and the Moldova-Transdniestria Conflict: Lessons in Mediation and Conflict Management. Security and Human Rights, 24. (2014), 3-4. 287-297. 294-295.

Európai Tükör 2020/3. 
$\mathrm{Az}$ 1995-ben megfogalmazott eredeti transznisztriai alkotmány ${ }^{36}$ csupán egy módosítással - a kétkamarás parlament egyesítéséről - máig hatályos. ${ }^{37} \mathrm{~A}$ hatalmi ágak szétválasztásának elve szerint kialakított rendszer egyes elemeit az alkotmány külön fejezetekben tárgyalja. Így a második fejezet a jogalkotás, a harmadik fejezet a végrehajtás, az ötödik fejezet pedig az igazságszolgáltatás rendszerének leírását tartalmazza. A kiépült és máig múködtetett alkotmányos berendezkedés részletesen kidolgozott és stabil rendszer képét festi, mégis éri kritika. Egyrészt az elnök rendkívül erőteljes szerepe és a végrehajtás további szerveinek alárendeltségéből fakadóan autoriter jellegű a hatalma, másrészt nem létezik civil szféra a térségben, a jogállamiság sem valósul meg, ezzel szemben a feketekereskedelem, hangsúllyal a drog-, fegyver-, de akár az emberkereskedelem valósággal virágoznak, főként (az el nem ismert) határokon. ${ }^{38}$

Kelet-Ukrajna esetében, a több résztvevős, a szemben álló ukrán és szeparatista csoportok és a szintén támadásokat végző orosz önkéntes katonai csoportok folyamatos fegyveres konfliktusai miatt a térségben ${ }^{39}$ a fegyverszünet elérése is igen nehéz feladatnak bizonyult, amit kizárólag nemzetközi közbenjárással sikerült elérni. A tárgyalássorozat útnak indulása az úgynevezett normandiai négyeknek köszönhető - 2014. június 6-án Angela Merkel német kancellár, François Hollande akkori francia elnök, Petro Porosenko ukrán elnök és Vlagyimir Putyin orosz elnök találkozásának eredménye a Trilaterális Csoport felállítása, ${ }^{40}$ a trilaterális tárgyalásoknak pedig két minszki dokumentumot köszönhetünk - egy protokollt és egy memorandumot. ${ }^{41}$

2014. szeptember 1-jére dolgozzák ki az első dokumentumot, ami egy fegyverszüneti egyezmény. A Trilaterális Csoportként ismert EBESZ, Ukrajna és Oroszország hármasa, a szervezet képviseletében Heidi Tagliavini, Oroszország ukrajnai delegáltja Mikhail Zurabov, ukrán részről pedig Leonyid Kucsma folytatta tárgyalások Petro Porosenko ukrán, és Vlagyimir Putyin orosz elnökök által képviselt álláspontok egyeztetésével az úgynevezett Minszki Protokollt dolgozta ki. A későbbi békeszerződésnek szánt további dokumentum fényében adott protokoll Minszk I. Egyezményként is ismert. Az első egyezmény 12 pontban foglalja össze a fegyverszünethez szükséges feltételeket. Ezek az azonnali fegyvernyugvás, az EBESZ felügyelete alatt zajló lefegyverzés, valamint a szervezet általi határellenőrzés, hadifoglyok szabadon engedése, törvény kidolgozása

\footnotetext{
36 Az alkotmányos rendszer bemutatása az alkotmány a szövegben megjelölt részeinek feldolgozásával történt, ez a felhasznált irodalom listájában angol nyelven elérhető forrás alatt megtekinthető. (Constitution of the Pridnestrovskaia Moldavskaia Respublica. 2010.)

37 John O'Loughlin - Vladimir Kolossov - Andrei Tchepalyga: National Construction, Territorial Separatism, and Post-Soviet Geopolitics in the Transdniester Moldovan Republic. Post-Soviet Geography and Economics, 39. (1998), 6. 332-358.

38 Helge Blakkisrud - Pål Kolstø: From Secessionist Conflict Toward a Functioning State: Processes of State- and Nation-Building in Transnistria. Post-Soviet Affairs, 27. (2011) 2. 178-210. 189-202. Vö. Félix Buttin: A Human Security Perspective on Transnistria Reassessing the Situation within the "Black Hole of Europe. Human Security Journal, (2007), 3. 13-28. 21-25.

392014 és 2015 során az Egyesült Nemzetek Szervezete 9100 halálesetet és 20700 sérültet tart számon. Forrás: https://www.ohchr.org/Documents/Countries/UA/12thOHCHRreportUkraine.pdf (A letöltés dátuma: 2019. 09. 26.)

40 Anna Hess Sargsyan: Unpacking Complexity in the Ukraine Peace Process. CSS Analyses in Security Policy, (2019), 243. 1-5. 1.

41 Tim B. Peters - Anastasija Shapkina: The Grand Stalemate of the Minsk Agreements. Sankt Augustin, Konrad-Adenauer-Stiftung, 2019. 1-3.
} 
és életbeléptetése a kelet-ukrajnai szeparatisták felelősségre vonására, nemzeti dialógus kialakítása, valamint a humanitárius körülmények javítása mellett az érintett térségek gazdasági fejlesztése is. A dokumentum emellett kimondja az irreguláris fegyveres csoportok felszámolását Ukrajna teljes területén. A dokumentumot a Donyecki Népköztársaság képviseletében Alekszandr Zaharcsenko, a Luhanszki Népköztársaság nevében pedig Igor Plotnyickij is ellenjegyezte. ${ }^{42}$

A Minszk II. dokumentum, a Minszk Memorandum néven is ismert második próbatétel a békekötésre a vitás felek között Kelet-Ukrajnában. 2015. február 12-én 13 pontban foglalta össze ugyanazon szerzőcsoport újonnan egy tartós béke feltételeit. Tartalmazza a február 15. nulla órától kötelező tűzszünetet, a meghatározott fegyverek kivonási kötelezettségét egy 50, illetve 70 kilométeres létrehozandó biztonsági övezetből. A lefegyverzés folyamatának ellenőrzése ismételten az EBESZ feladataként jelenik meg. Szintén visszatérő elem a nemzeti dialógus és a lázadók számára biztosítandó amnesztia, a foglyok elengedése, cseréje. Kitérnek a humanitárius segélyek biztosítására a rászoruló térségek felé, illetve a konfliktusos határterület ellenőrzését Ukrajna ellenőrzése alá vonják. Az idegen erők kivonása mellett megjelenik a donyecki és luhanszki térségben demokratikus regionális választások tartásának szükségessége. Fontos kiemelni a szakadár entitások fegyverszüneti egyezményeinek célkitűzései közötti különbséget, miszerint Ukrajna esetében a kivált egykori oblasztyok teljes visszaintegrálásáról döntöttek a részt vevő felek. ${ }^{43}$

Ahogy az első dokumentum, a második Minszki Egyezmény is sikertelennek bizonyult. A nem nyugvó harcok feloldására elsőként a Steinmeyer protokoll íródott, majd 2016. október 19-én a Normandiai Négyek találkozóján is kidolgoznak egy akciótervet - mindkét dokumentum a Minszki Memorandumban foglaltak végrehajtási terveként jött létre, de egyik sem valósult meg. ${ }^{44} \mathrm{~A}$ béketervezet az előbbiekben felsorolt elemei közül nem implementálták a tűzszünetet, az amnesztia feltételét, nem valósult meg a humanitárius segély, a határellenőrzés továbbra sem tartozik Ukrajna hatáskörébe, továbbra is tartózkodnak külföldi erők az ország területén, és demokratikus választásokra sem került sor a leválasztott területeken. ${ }^{45}$ Utóbbi feltétellel szemben a kezdetektől általános a szkepticizmus - egy erőszakkal elszakított és autoriter jelleggel kiépített rendszerben megkérdőjelezhető a demokratikus választások lehetősége. ${ }^{46}$

\section{Nemzetközi viszonyok - viszontagságok}

Habár a vizsgált entitások a tanulmány bevezetésében tárgyaltak szerint nem minősülnek államnak, megjelennek nemzetközi szervezetek föként segélyprogramjaiban,

\footnotetext{
$42 \quad$ Protocol on the Results of Consultations of the Trilateral Contact Group. 2014.

43 Minsk II. Package of measures for the Implementation of the Minsk agreements. 2015.

$44 \quad$ Sabine Fischer: The Donbas Conflict: Opposing Interests and Narratives, Difficult Peace Process. German Institute for International and Security Affairs, SWP Research Paper 5, 2019.

45 Nadja Bentzen: A UN peacekeeping mission in eastern Ukraine?, European Parliamentary Research Service, 2019. 1.

46 Katarzyna Pełczyńska-Nałęcz - Piotr Buras: The Minsk (dis)agreement and Europe's security order. Varsó, Stefan Bathory Foundation, 2017. 6.
} 
állásfoglalásaiban, illetve sajátosan kivitelezett nem állami szintű, de mégis államközi kapcsolatként kezelt viszonyok kiépítésére is törekednek.

Transznisztria esetében először a nemzetközi szervezetekkel létesített kapcsolatát vizsgálom. A leginkább meghatározó, nemcsak mint előremutató segítségnyújtási törekvés a békekötésre, de mint európai szerepvállalás is az Európai Biztonsági és Együttmüködési Szervezet 1993. április 27-én indított missziója Moldovába. ${ }^{47}$ Eredetileg hat hónapos intervallumra tervezték, azonban folyamatosan meghosszabbították. Ennek célja a hosszú távú béke elősegítése és a térségi katonai jelenlét felszámolása mellett megfigyelés és információgyüjtés, valamint -szolgáltatás, kiemelten az emberi jogok és a kisebbségi kérdések kapcsán. ${ }^{48}$

Az Európai Unió (EU) kizárólag Moldovát támogatja mind a konfliktusban, mind nemzetközi színtéren, 2003 óta személyi szankciókat is fenntartanak a transznisztriai politikai elittel szemben. 2004-ben Moldovát is bevonták az Európai Szomszédságpolitika programjába, aminek eredményeképpen 2005 óta speciális képviseletet ellátó delegációt működtetnek a fővárosban, Kisinyovban. ${ }^{49}$ Szintén ez évben indult útjára a European Union Border Assistance Mission to Moldova - az Európai Unió határtámogató missziója Moldovában. Ennek keretein belül az integráció 18 tagállamából összesen 126 főt delegáltak a térségbe, szintén kisinyovi központtal. Az eredetileg két évre tervezett projektet folyamatosan meghosszabbították, a célja a technikai segítségnyújtás. ${ }^{50}$ Az együttműködés az Unióval a 2010-es évek elejére csak tovább erősödött, kiteljesedése a 2013-as Vilniusi Együttmúködési Megállapodás (az a szerződés, ami Ukrajna számára meghiúsult). ${ }^{51}$ Ennek értelmében az integráció szabadkereskedelem kiépítésére törekszik Moldovával, aminek keretein belül Transznisztria autonóm kereskedelmi preferenciákat élvezhet. ${ }^{52}$

Az Európai Unió integrációs tevékenysége és a regionális nemzetközi szervezet, azon belül is kiemelten a keleti térség és a Visegrádi Négyek gazdasági közelítése Moldova felé a bemutatott konfliktus következtében azonban nagymértékben visszaesett. A nyugati partnerek szerepvállalásának csökkenésével párhuzamosan egy más, az eddigiekben is fenntartott kapcsolat jelentősége kezdett növekedésbe. Ezáltal az Orosz Föderáció, kifejezetten az általa alapított és múködtetett Eurázsiai Gazdasági Unió lett a transznisztriai anyaállam és ezáltal a szakadár entitás gazdasági kapcsolatainak keleti alternatívája. ${ }^{53}$ Oroszország emellett nem csupán az európai gazdasági kapcsolatokat kiegészítő potenciális partnerként van jelen a moldovai gazdaságban. Moldova egyrészt a Dnyeszter menti szakadár entitás által térítés nélkül felhasznált orosz nyersanyagból fakadó milliárdos nagyságrendủ felhalmozott tartozása miatt, de a saját fogyasztását is

$47 \quad$ Report No. 13 by the CSCE Mission to Moldova. OSCE, 1993.

48 Stefan Troebst: Kein spektakulärer Erfolg, aber Spannungen reduziert - Die OSZE in der Republik Moldova. Wissenschaft \& Frieden, (1997), 1. Vö. Gottfried Hanne: The Role and Activities of the OSCE Mission to Moldova in the Process of Transdniestrian Conflict Resolution. Leiden, Martinus Nijhoff Publishers, 2004. 31-34.

49 Marius Vahl: The Europeanisation of the Transnistrian Conflict. CEPS Policy Brief No. 73, 2005. 2-4.

50 European Union Border Assistance Mission to Moldova and Ukraine (EUBAM) PC.DEL/983/12. 2012.

51 William H. Hill: Is Moldova Headed East? Kennan Cable, (2015), 8. 1-6. 2.

52 Benedikt Harzl: Keeping the Transnistrian conflict on the radar of the EU. Österreichische Gesellschaft für Europapolitik Policy Brief 24, 2016. 3.

53 Barabás T. János: Moldova, Ukrajna és Belarusz közös utakon. KKI Elemzések, (2017), 32. 3-9. 3-4. 
kizárólag orosz energiaforrásból fedezve egészségtelen függésbe került az Orosz Föderációtól. ${ }^{54}$

Az Észak-atlanti Szerződés Szervezete (NATO) szintén kizárólag Moldovával épített ki kapcsolatot. A köztársaság 1992-ben kötött partnerségi szerződést a szervezettel, ${ }^{55}$ és habár Moldova rendszeresen lobbizik Transznisztria ellen a katonai szervezetben, a NATO egyszerűen elzárkózik az entitással történő közvetlen kapcsolat kiépítésétől. ${ }^{56}$

Az Egyesült Nemzetek Szervezete szintén csak Moldovával működik együtt, habár bizonyos fejlesztési programjai hatással vannak a transznisztriai régióra is, kifejezetten az emberi jogok és az egészségügy fejlesztésére. ${ }^{57}$

Ezzel párhuzamosan Transznisztria a nemzetközi viszonyok tekintetében önkéntesen és kényszeredetten is Kelet felé sodródik. Egyrészt aszimmetrikus függésben van Oroszországtól, tekintve, hogy amerikai dollárban mérve is milliárdos nagyságrendű tartozása van az ortodox állam felé. Emellett kiszolgáltatott az entitás helyzete a kizárólag Oroszországból érkező gázellátás és a máig fennálló katonai jelenlét miatt is. ${ }^{58}$ Másrészt nemzetközi kapcsolatai kimerülnek a posztszovjet térség további, hasonló státuszszal - státusz nélküliséggel - rendelkező entitásaival és magával az Orosz Föderációval fenntartott viszonyokban. Abházia, Dél-Oszétia és Hegyi-Karabah kölcsönösen bírnak egymás idézőjeles „elismerésével”. ${ }^{59}$ 2006-ban ezen entitások hozták létre az úgynevezett Sukhum-nyilatkozattal a Közösség a Demokráciáért és az Államok Jogaiért nevű nemzetközi szervezetet, amit a nemzetközi közösség szerencsétlen módon csupán az El nem ismert Államok Közösségeként ismer. ${ }^{60}$ Emellett, Transznisztria egyetlen számontartott képviselete az Orosz Föderációban található. A képviseleti egység fizikai megvalósulását 2006-os találkozó előzi meg a transznisztriai Szmirnov elnök személyes részvételével. Az ekkor folytatott tárgyalások során „dinamikusan fejlődő, kölcsönösen előnyös” kapcsolatok és „stratégiai partnerség” megvalósításáról tárgyalnak, aminek megvalósítására gazdasági, társadalmi és tudományos bilaterális kapcsolatok kiépítését irányozzák elő. ${ }^{61}$ A diplomáciai képviselet általános feladatai közé tartozik a köztársaság képviselete, politikai érdekérvényesítés, kiemelten a kereskedelem, a gazdaság, pénzügy, tudomány és kultúra területein. Emellett feladata előremozdítani az esetleges regionális együttműködéseket, szervezeti tagságot, valamint részvételét konferenciákon és fórumokon. A 2019 januárja óra működő moszkvai képviselet, élén Leonyid Manakovval speciális célként emeli ki ezek mellett a hivatalok mellett a Dnyeszter-menti Köztársaság

$54 \quad$ Vasa László: A moldovai gazdaság helyzete 2018-ban és jövőbeni kilátása. KKI Elemzések, (2018), 52. 3-5.

55 Relations with the Republic of Moldova. NATO, 2018.

$56 \quad$ Statement. NATO, 1998.

57 Vö. United Nations in Moldova-Joint Action to Strengthen Human Rights in the Transnistrian Region of the Republic of Moldova; United Nations in Moldova - Empowerment of Victims of Domestic Violence and Human Trafficking in the Transnistrian region of Moldova; First Medical Training Center opens in Tiraspol. United Nations in Moldova, 2018.

58 Anita Sobják: Is Transnistria the Next Crimea? PISM Bulletin, 49. (2014), 644. 1-2. 2.; Vö. Paul Ivan: Transnistria - Where to? European Policy Centre Policy Breaf, 2014. 4.

59 Ludger Kühnhardt: The Global Society and Its Enemies: Liberal Order Beyond the Third World War. Cham, Springer, 2017. 84.

$60 \quad$ Community for Democracy and Rights of States. 2007.

61 Communiqué on the results of the meeting between President of TR I. Smirnov and Vice-Chairman of the Russian Cabinet A. Zhukov. Ministry of Foreign Affairs of Pridenstrovian Moldavian Republic, 2006.

Európai Tükör 2020/3. 
és az Orosz Föderáció civil szférái közötti együttműködést, a transznisztriai igények képviseletét, valamint az információcsere és a publikációk kiadása és a konferenciák szervezése mellett megjelöli a köztársaság integrálását az orosz kulturális egységbe. ${ }^{62}$

A Donyecki Népköztársaság és a Luhanszki Népköztársaság kapcsolatrendszerének vizsgálata során is a nemzetközi szervezetek, elsősorban az Európai Biztonsági és Együttmúködési Szervezethez fűződő viszonyt írják le. A regionális biztonsági szervezet szerepvállalása egyrészt nemzetközi együttmúködés keretein belül valósul meg - ez a békekötés folyamán betöltött szerepe. Ennek értelmében 2014 óta aktívan részt vállal a tárgyalások elősegítésében a korábban már részletezett trilaterális együttműködés és a Normandiai Négyessel folytatott tárgyalások során és ezzel a fegyverszünet és az esetleges békekötés előremozdításában is. A szervezet által támogatott és lehetővé tett együttmúködés eredménye a korábban szintén feldolgozott, a kelet-ukrajnai háborús helyzete feloldását célzó Minszk I. és Minszk II. fegyverszüneti és béketervezetek is. ${ }^{63}$

A nemzetközi kooperáció elősegítése, végrehajtása és az abban zajló részvétel mellett az Európai Biztonsági és Együttmúködési Szervezet önálló fellépéssel is jelen van a vizsgált térségben. A 2013. év végi és 2014. év eleji események, kifejezetten a keletukrajnai folyamatok szélsőségesedése következtében az EBESZ, amely a transznisztriai missziót is múködteti, 2014. március 21-én az EBESZ-tagállamok plenáris ülésén hozott 1117. számú döntésével egy speciális megfigyelő misszió delegálásáról döntöttek Ukrajnába. A szervezet 40 tagállamából összesen 700 fegyvertelen megfigyelőstátusszal rendelkező civilből álló misszió a donyecki és luhanszki térségekre koncentrál, megközelítőleg 600 itt elhelyezett megfigyelővel. A misszió célja a törékeny béke és stabilitással szemben Ukrajna támogatása, információgyújtés a hatalmi rendszerekről, a civil szféráról, etnikai és vallási csoportok helyzetéről a vitás felek közötti dialógus elősegítése és a feszültségek csökkentése érdekében. A misszió időtartamát eredetileg hat hónapban határozták meg, ami nemcsak megújítható, de azóta is folyamatosan aktív. ${ }^{64}$

Tekintve, hogy magát a missziót az ukrán kormány kérésére, az Európai Biztonsági és Együttmúködési Szervezet tagállamainak jóváhagyásával hívták életre, az EBESZ szerepvállalásával kapcsolatban is megállapítható, hogy kizárólag Ukrajnával működik együtt, habár a megfigyelők zöme a vizsgált kelet-ukrajnai entitások térségében tartózkodik, azok tevékenységének célja a terület konfliktusának felszámolásával Ukrajna és ezzel a kelet-európai térség stabilitásának visszaállítása, közvetlen kapcsolat itt sem lelhető fel.

Az Európai Unió által indított EUBAM-misszió, amelyet a transznisztriai kapcsolatoknál a tanulmány e fejezetének korábbi bekezdésében már bemutattunk, lesz az a misszió, amit 2015. november 24-én kiterjesztenek Ukrajna térségére is. A feladatkör ugyanaz, kiemelt hangsúllyal a határellenőrzés feladatára. ${ }^{65}$

\footnotetext{
62 Official Representation of the Pridnestrovian Moldavian Republic in Moscow. Ministry of Foreign Affairs of Pridenstrovian Moldavian Republic, 2019.

63 Trilateral Statement by the Trilateral Contact Group. OSCE, 2015.

64 Decision No. 1117 Deployment of an OSCE Special Monitoring Mission to Ukraine. OSCE, 2014; Special Monitoring Mission (SMM) to Ukraine: The Facts. OSCE, 2016.

65 Addendum to Memorandum. OSCE, 2005.
} 
Ukrajna 1991 óta áll partnerségi szerződésben a NATO-val. A konfliktus kapcsán a védelmi szervezet tagállamai egyöntetűen Oroszország agresszív fellépését ítélik el, és a keleti régió destabilizálódásáért is az államot teszik felelőssé. Az Észak-atlanti Szerződés Szervezete így nem csak az ukrán haderő fejlesztését és növelését támogatja, 2016-ban elindította az Átfogó Támogatás csomagját, ami 2018-ban a Partnerségi Célkitűzés csomaggal párosult - mindkét program az állam stratégiai és védelmi képességeinek reformját támogatja. A nemzetközi szervezet tehát egyértelműen és nyíltan az ukrán szuverenitás és területi integritás mellett áll ki, nincs kapcsolata a szeparatista entitásokkal. ${ }^{66}$

Az Egyesült Nemzetek Szervezete is hasonló álláspontot képvisel. A 2014. március 27-i 68/262. számú Közgyúlési határozatban foglaltak szerint Ukrajna területi integritásának tiszteletben tartása mellett a 2015. február 17-i Biztonsági Tanács 2202. számú határozatában a Minszk Memorandum rendelkezéseinek betartására és végrehajtására szólítják fel az érintetteket. A határozatok mellett az Egyesült Nemzetek Szervezetének a konfliktussal kapcsolatos szerepvállalásához sorolhatók a szervezet Főtitkárának rendszeres sajtónyilatkozatai. Tekintve, hogy ezek tartalma főként Pan Gimun akkori főtitkár aggodalmát fejezik ki a térségben az agresszióval kapcsolatban, mint a fegyverhasználat vagy a személyekkel szemben elkövetett atrocitások elítélése, az entitásokat nem érintik, így további részletezést nem érdemelnek. ${ }^{67} 2014$ márciusában az ENSZ delegálja az Emberi Jogi Megfigyelő Misszióját (UN Human Rights Monitoring Mission) Ukrajnába. A célkitűzés a megfigyelés és jelentés, illetve a központi kormány segítése az emberi jogi jogvédelmi kérdésekben. Öt helyszínre helyeztek megfigyelőket, ezek Kijev, Donyeck, Odessza, Harkov és Lvov városai, ennek értelmében jelen vannak a Donyeck régióban, így jelentéseik relevánssá válnak jelen értekezés témájával kapcsolatban. 2014 áprilisa óta 2019 szeptemberéig összesen 33 jelentést készítettek, amelyek mindegyike tartalmaz megállapításokat a kelet-ukrajnai térségre nézve is. ${ }^{68}$

Ezen a ponton megállapíthatóvá válik, hogy az Egyesült Nemzetek Szervezete nem tart fenn kapcsolatot a szakadár entitásokkal - sőt, a vizsgált dokumentumokkal alátámasztható, hogy állásfoglalásában szembehelyezkedik velük, elítélve az agressziót, a jogtalanságot, az erőszakot, az emberi jogi jogsértéseket, az alapvető

$66 \quad$ Relations with Ukraine. NATO, 2019.

67 A 2015. január 14-i, 22-i, valamint 24-i, április 17-i és augusztus 17-i nyilatkozatok angol nyelvŭ elérhetősége az irodalomjegyzékben tételesen megtalálható. United Nations Resolution adopted by the General Assembly on 27 March 2014 [without reference to a Main Committee (A/68/L.39 and Add.1)] 68/262. Territorial integrity of Ukraine; Security Council Press Statement on Killing of Civilians at Public Transport Stop in City of Donetsk. Statement of UN Secretary-General, January 22 2015; United Nations Resolution 2202 (2015) Adopted by the Security Council at its 7384 ${ }^{\text {th }}$ meeting, on 17 February 2015; Secretary-General Expresses Concern over Killings of Prominent Persons in Ukraine. Statement of UN Secretary-General, April 172015.

Disturbed by Escalating Fighting in Ukraine, Secretary-General Urges All Concerned to Restore Peace, Ensure Territorial Integrity. Statement of UN Secretary-General - 2015. January 14;

Condemning Rocket Attack on Mariupol, Ukraine, Rebels' Withdrawal from Ceasefire Agreement, SecretaryGeneral Urges All Parties to Revive Minsk Accords. Statement of UN Secretary-General - January 242015 ; Secretary-General Alarmed at Escalation of Violence in Eastern Ukraine, Urges Adherence by Both Sides to Minsk Agreements, Including on Heavy Weapons Use. Statement of UN Secretary-General - 17 August 2015.

68 Human Rights Monitoring Mission in Ukraine. United Nations, 2019.

Európai Tükör 2020/3. 
szabadságjogok érvényesülésének a hiányát. Ukrajna területi integritását támogatva, elzárkózik a kelet-ukrajnai szeparatista államtöredékektől, kizárólag megfigyelőként volt jelen a konfliktusban és van jelen napjainkban az entitások térségében. A Donyecki és Luhanszki Népköztársaságok ennek megfelelően egy más állam elismerésével sem bírnak. Ettől függetlenül, a vizsgált entitások hivatalos-nem hivatalos weboldalukon nemzetközi viszonyoknak számító tevékenységet igyekeznek bemutatni. A Donyecki Népköztársaság esetében a diplomáciai képviselet fül alatt úgynevezett információs irodák múködtetéséről tájékoztatnak, amelyek elméletileg megtalálhatók Görög-, Olasz-, Cseh-, és Franciaországban. A Luhanszki Népköztársaság emellett a diplomáciai kapcsolatai között tünteti fel a Velence városával folytatott levelezését is.

Az ukrajnai szeparatista entitások csökevényes vagy nem létező nemzetközi reprezentációs törekvései, valamint a Moldovai esethez hasonlóan a nemzetközi szervezetek elutasító állásfoglalásának következtében, a függetlenségre törekvő entitásokkal szemben még fontosabbá válik azok Orosz Föderációhoz fúződő viszonya. A Kelet-Ukrajna régió a korábbiakban leírt kulturális és történelmi szoros kapcsolat mellett annak keleti szomszédos nagyhatalmával, a transznisztriai térséghez hasonlóan, itt is megjelenik a gazdasági érdek. A korábbiakban már említett Eurázsiai Gazdasági Unió számára nemcsak Moldova, de Ukrajna is értékes partner lehet. A gazdasági kapcsolatok nem merülnek ki az integrációs törekvésekben, Ukrajna esetében is kiemelendő az energiaszektor függése az orosz nyersanyagtól. Emellett, a tanulmány első fejezetében kiemelt vallási diverzió is erősíti a kelet felé sodródást, tekintve, hogy a Moszkvai Patriarchátus alá tartozó térségek nyilvánvalóan a keleti integrációt támogatják a nyugati európai uniós törekvésekkel szemben. ${ }^{69}$ Ezen szoros kapcsolat - vagy függési viszony - a szeparatizmus térnyerésekor Ukrajna keleti térségében megalapozza az Orosz Föderáció szerepvállalását. Az Ukranja keleti határvidékén keresztül Oroszország nemcsak fegyverben és haditechnikában megtestesülő segítséget nyújt a szakadár entitásoknak, de az ukrán közigazgatás kiiktatását követően a térségben a humanitárius válságot elkerülendő logisztikai és pénzügyi segélyekkel is segíti az itt élőket. A konfliktus során továbbá emberi erőforrás is érkezik a keleti államból, de hivatalosan kizárólag önkéntesek személyeiben, az orosz haderőt nem vonták bele a konfliktusba. ${ }^{70}$

\section{Következtetések}

A tanulmányba foglaltakban feldolgozott információk alapján levont következtetések közül elsőként a térségek státuszát tárgyalnám - röviden, mivel a Jellinek-féle megközelítést jelen tanulmányban többször is említettem az események és körülményeik bemutatása során. Első megállapításom, hogy az általam vizsgált entitások sem a szuverenitás

69 Neil Kent - Vsevolod Samokhvalov: The Ukraine crisis: a Russian-European cold war? Journal of Intelligence and Terrorism Studies, (2016), 1. 1-11. 8-9.

70 Anton Bebler: Crimea and the Russian-Ukrainian Conflict. Romanian Journal of European Affairs, 15. (2015), 1. 35-54. 47-48. 
vizsgálata, sem a nemzetközi jogi elvárások szerint nem nevezhetők államnak ${ }^{71}$ még ha annak funkciót sajátos, néhol kicsavart megoldásokkal mégis képesek ellátni. Így valósulnak meg a leginkább nem államközi módon múködő, a harmadik fejezetben tárgyalt főként szubállami jellegű, bár az entitások által államközi kapcsolatokként listázott kapcsolatok, valamint az illegálisan, agresszióval, az anyaállam területi integritásának, a nemzetközi jog és az Egyesült Nemzetek Szervezetének alapokmányába foglaltaknak megsértésével megszerzett és irányításuk alá vont, ismételten csupán idézőjelesen említhető „állami” terület. A második fejezetben szintén vizsgálat alá vont kiépült rendszer elnagyolt, működése korrupt, a demokráciát messziről elkerüli - ettől függetlenül a jellineki hármasból vagy a montevideói négyesből talán ez az egyetlen olyan elem, amely kétségek nélkül valóban beteljesültnek tekinthető.

További következtetésem, hogy a leírt események mindkét térség esetében túlléptek a regionális hatáson, tekintve a nemzetközi visszhangot, amely bemutatására jelen tanulmány teljes terjedelmében az események vizsgálatával párhuzamosan törekedtem kitérni, végül a dokumentum utolsó fejezetében koncentrálva tárgyaltam. A nemzetközi szerepvállalás, ami a leírtak szerint főként nemzetközi szervezetek tevékenységén és kommunikációján keresztül valósul meg. Ezáltal - bizonyítandó előfeltételezésem - a vizsgált egységek önálló kapcsolatokkal nem rendelkeznek a nemzetközi szerepvállalás következtében sem. A fellépő egységek egyöntetűen az anyaországok területi integritása mellett állnak ki. Emellett fontos tulajdonságuk, hogy a béketeremtő tevékenységük nemcsak a saját területükön kívül eső konfliktus rendezésében játszanak kardinális fontosságú szerepet, de ezáltal saját, hosszú távú békéjük fenntartását is szolgálják a geopolitikai stabilitás növelésével - vagy azon törekvésükkel.

Ennek értelmében, az európai és nemzetközi szerepvállalás mindössze biztonságpolitikai kihívásra történő reakció. Az esettanulmányokban foglaltak egyértelművé teszik, hogy kizárólag a stabilitás helyreállítására törekszenek, tevékenységük során elhatárolódnak a tárgyalt államtöredékektől, kizárólag a béketeremtésre koncentrálnak. Az esetleges kapcsolat alatt csupán az anyaországgal folytatott fejlesztési és/vagy humanitárius projektek és programok, missziók vagy akár a vitás felek közötti tárgyalás elősegítéséből fakadó jelenlét vagy kontaktus értendő. A vitatott térségben a nemzetközi jelenlét tehát nem politikai állásfoglalás, hanem geopolitikai kényszer.

Az Európai Unió stratégiai kapcsoltépítése, mint a korábbiakban már említettem Európai Szomszédságpolitika, a Keleti Partnerség vagy akár a társulási szerződések által előremozdítani kívánt együttműködés politikai és államépítési területen viszonylagos előrelépésekhez és fejlődéshez vezetett a vizsgált entitások berendezkedésében, hiába azonban a támogató gazdasági programok, ha a célterületek nem fogékonyak azok végrehajtására, megvalósítására. ${ }^{72} \mathrm{~A}$ tanulmányban bemutatott konfliktusoknak köszönhetően az eddigiekben is félsikereket elkönyvelő európai uniós kapcsolatok jelentősen csökkentek, ezáltal új partnerek felé kényszerítve a vizsgált államokat. Az európai

\footnotetext{
71 Vö. Fejes Zsuzsanna: Az állam, mint a nemzetközi együttmúködés szereplője. A globalizáció és az állam megváltozott szerepe a nemzetközi viszonyokban. In Fejes Zsuzsanna - Szalai Anikó (szerk.): Államközi kapcsolatok. Szeged, Iurisperitus, 2019. 61-77.; Fejes Zsuzsanna: The State as an Actor of International Cooperation. Globalization and the Changed Role of State in International Relations. In Fejes Zsuzsanna - Sulyok Márton - Szalai Anikó (szerk.) Interstate relations. Szeged, Iurisperitus, 2019. 57-72. Vasa (2018) i. m. 4.
} 
regionális integráció kezét elengedve a vizsgált entitások Kelet felé, az Orosz Föderáció irányába sodródnak, és a már eddigiekben is létező kiszolgáltatottságuk tovább erősödik annak irányába. Az orosz szerepvállalás nem csupán a nemzetközi viszonyok bemutatásakor leírt gazdasági integrációs törekvésekben, politikai közelítésben, vagy kiemelten Ukrajna esetében a konfliktus fegyveres támogatásában valósult meg, jelentős szerepet vállalt az állam és politikai vezetősége a tárgyalássorozatok kivitelezésében is. Visszautalva a tanulmány második fejezetére, kiemelten Moldova esetében a Moszkvai Memorandumot és a Moszkvai Protokollt, vagy Ukrajna esetében a Normandiai Négyesben Putyin orosz elnök, a Trilaterális Bizottságban pedig Oroszország részvételét. A keleti nagyhatalom ezáltal nem csak történelmileg kötődik az adott térségekhez, de a fegyveres konfliktust végigkísérte, egyes esetekben aktívan részt vett benne, illetve azóta is nagy szerepet vállal azok kezelésében mediátor szerepében, miközben gazdasági érdekeit is igyekszik érvényesíteni.

Az akár kontinentális, akár integrációs Európa számára ezáltal a konfliktusos térségekhez fűződő kapcsolatának kialakítása, visszaállítása még fontosabbá válik annak gazdasági és politikai jellegú átvezető szerepének megtartása érdekében. Az egyre növekvő orosz szerepvállalás és befolyás növekedésével szemben az európai szerepvállalás kialakítása, visszaállítása nemcsak politikai, de gazdasági fontosságú is volna.

\section{Felhasznált irodalom}

Addendum to Memorandum. OSCE, 2005. Elérhető: http://eubam.org/wp-content/uploads/2015/12/Addendum-1-to-MoU-EC_English-version.pdf (A letöltés dátuma: 2019. 09. 27.)

Agreement on the Principles for a Peaceful Settlement of the Armed Conflict in the Dniester Region of the Republic of Moldova. 1992. Elérhető: https://peacemaker.un.org/sites/ peacemaker.un.org/files/MD\%20RU_920000_AgreementPrinciplesPpeacefulSettlementDniestrConflict.pdf (A letöltés dátuma: 2018. 11. 05.)

Arday Lajos: Ukrajna - történelem, etnikum, identitás. International Relations Quarterly, 5. (2014), 1. 1-7.

Barabás T. János: Moldova, Ukrajna és Belarusz közös utakon. KKi Elemzések, (2017), 32. 3-9.

Bebler, Anton: Crimea and the Russian-Ukrainian Conflict. Romanian Journal of European Affairs, 15. (2015), 1. 35-54.

Belitser, Natalie (szerk.): Trilateral Plan for Solving the Transnistrian Issue. Bucharest-Chisinau-Kijev, Foundation for Open Society, 2006.

Bentzen, Naja: A UN peacekeeping mission in eastern Ukraine? European Parliamentary Research Service, 2019.

Besters-Dilger, Juliane (szerk.): Ukraine on Its Way to Europe - Interim Results of the Prange Revolution. Frankfurt am Main, Peter Lang GmbH, 2009.

Blakkisrud, Helge - Pål Kolstø: From Secessionist Conflict Toward a Functioning State: Processes of State- and Nation-Building in Transnistria. Post-Soviet Affairs, 27. (2011), 2. 178-210. DOI: https://doi.org/10.2747/1060-586X.27.2.178 
Buttin, Félix: A Human Security Perspective on Transnistria Reassessing the Situation within the "Black Hole of Europe. Human Security Journal, (2007), 3. 13-28.

Comai, Gregorio - Bernardo Venturi: Language and education laws in multi-ethnic de facto states: the cases of Abkhazia and Transnistria. Nationalities Papers, 43. (2015), 6. 886-905. DOI: https://doi.org/10.1080/00905992.2015.1082996

Community for Democracy and Rights of States. 2007. Elérhető: http://mfa-pmr.org/ru/gnk (A letöltés dátuma: 2018. 11. 28.)

Communique on the results of the meeting between President of TR I. Smirnov and Vice-Chairman of the Russian Cabinet A. Zhukov. Ministry of Foreign Affairs of Pridenstrovian Moldavian Republic, 2006. Elérhető: http://mfa-pmr.org/en/hjd (A letöltés dátuma: 2020. 03. 18.)

Condemning Rocket Attack on Mariupol, Ukraine, Rebels' Withdrawal from Ceasefire Agreement, Secretary-General Urges All Parties to Revive Minsk Accords. Statement of UN Secretary-General, January 24 2015. Elérhető: www.un.org/press/en/2015/ sgsm16485.doc.htm (A letöltés dátuma: 2019. 11. 11.)

Constitution of the Pridnestrovskaia Moldavskaia Respublica. 2010. Elérhető: http://mfapmr.org/en/bht (A letöltés dátuma: 2018. 11. 21.)

Coppieters, Bruno - Michel Huysseune - Tamara Kovziridze - Gergana Noutcheva Nathalie Tocci - Michael Emerson - Marius Vahl: Europeanization and Conflict Resolution - Case Studies from the European Periphery. Gent, Academia Press, 2009.

Decision No. 1117 Deployment of an OSCE Special Monitoring Mission to Ukraine. OSCE, 2014. Elérhető: www.osce.org/pc/116747?download=true (A letöltés dátuma: 2018. 03. 07.)

Dima, Nicholas: From Moldavia to Moldova - The Soviet-Romanian Territorial Dispute. East European Monographs, New York, Columbia University Press, 1991.

Disturbed by Escalating Fighting in Ukraine, Secretary-General Urges All Concerned to Restore Peace, Ensure Territorial Integrity. Statement of UN Secretary-General, 2015. Elérhető: www.un.org/press/en/2015/sgsm16461.doc.htm (A letöltés dátuma: 2019. 11. 11.)

Empowerment of Victims of Domestic Violence and Human Trafficking in the Transnistrian region of Moldova, United Nations in Moldova, Elérhető: www.md.undp.org/content/moldova/en/home/operations/projects/inclusive_growth/proiecte-finalizate/empowerment-of-victims-of-domestic-violence-and-human-traffickin.html (A letöltés dátuma: 2018. 11. 27.)

European Union Border Assistance Mission to Moldova and Ukraine (EUBAM) PC. DEL/983/12. 2012. Elérhető: www.osce.org/pc/97531?download=true (A letöltés dátuma: 2018. 11. 25.)

Fejes Zsuzsanna: Az állam, mint a nemzetközi együttműködés szereplője. A globalizáció és az állam megváltozott szerepe a nemzetközi viszonyokban. In Fejes Zsuzsanna - Szalai Anikó (szerk.): Államközi kapcsolatok. Szeged, Iurisperitus, 2019. 61-77.

Fejes, Zsuzsanna: The State as an Actor of International Cooperation. Globalization and the Changed Role of State in International Relations. In Fejes Zsuzsanna - Sulyok Márton - Szalai Anikó (szerk.) Interstate relations. Szeged, Iurisperitus, 2019. 57-72.

Európai Tükör 2020/3. 
First proposal on a special status for Transdniestria, considered a basis for the negotiating process. OSCE, 1993. Elérhető: www.osce.org/moldova/42307?download=true (A letöltés dátuma: 2018. 11. 02.)

Font Márta: A Kijevi Rusz létrejöttének körülménye. História, 21. (1999), 9-10. 41-44.

Font Márta - Varga Beáta: Ukrajna története. Szeged, JATE Press, 2013.

First Medical Training Center opens in Tiraspol. United Nations in Moldova, 2018. Elérhető: http://md.one.un.org/content/unct/moldova/en/home/presscenter/press-releases/first-medical-training-center-opens-in-tiraspol.html (A letöltés dátuma: 2018. 11. 27.)

Fischer, Sabine: The Donbas Conflict: Opposing Interests and Narratives, Difficult Peace Process. German Institute for International and Security Affairs, SWP Research Paper 5, 2019.

Hajda, Lubomyr A.: Ukraine. Encyclopaedia Britannica, 2020. Elérhető: www.britannica. com/place/Ukraine (A letöltés dátuma: 2020. 04. 21.)

Hajdú-Moharos József: Fehéroroszország, Ukrajna, Moldávia. Budapest, ELTE Házinyomda, 1995.

Hanne, Gottfried: The Role and Activities of the OSCE Mission to Moldova in the Process of Transdniestrian Conflict Resolution. Leiden, Martinus Nijhoff Publishers, 2004.

Harbo, Florentina: Can Federalism Cope with the Challenges of the Transnistrian Conflict? In Monica Heintz (szerk.): Weak State, Uncertain Citizenship: Moldova. Frankfurt am Main, Peter Lang, 2008. 185-188.

Harzl, Benedikt: Keeping the Transnistrian conflict on the radar of the EU. Österreichische Gesellschaft für Europapolitik Policy Brief 24, 2016.

Heinzt, Monika (szerk.): Weak State, Uncertain Citizenship: Moldova. Frankfurt am Main, Peter Lang, 2008.

Hess Sargsyan, Anna: Unpacking Complexity in the Ukraine Peace Process. CSS Analyses in Security Policy, (2019), 243. 1-5.

Hildebrandt, Reinhard: Die Ukraine - Grenzland oder Brücke? Reflexionen zum aktuellen Konflikt. Frankfurt am Main, Peter Lang, 2015. DOI: https://doi.org/10.3726/9783-653-06292-2

Hill, William H.: The OSCE and the Moldova-Transdniestria Conflict: Lessons in Mediation and Conflict Management. Security and Human Rights, 24. (2014), 3-4. 287297. DOI: https://doi.org/10.1163/18750230-02404015

Hill, William H.: Is Moldova Headed East? Kennan Cable, (2015), 8. 1-6.

Human Rights Monitoring Mission in Ukraine. United Nations, 2019. Elérhető: www.un.org. ua/en/information-centre/news/1870 (A letöltés dátuma: 2019. 11. 11.)

Igari Léna: Vérontás: Ukrajna a polgárháború szélén. Hetek, 18. (2014), 8. 3.

Ivan, Paul: Transnistria - Where to? European Policy Centre Policy Breaf, 2014.

Jellinek, Georg: Allgemeine Staatslehre. Berlin, Verlag von O. Häring, 1914.

Joint Action to Strengthen Human Rights in the Transnistrian Region of the Republic of Moldova, United Nations in Moldova. Elérhető: www.md.undp.org/content/moldova/en/home/projects/joint-action-to-strengthen-human-rights-in-the-transnistrian-3.html (A letöltés dátuma: 2018. 11. 27.) 
Joint Statement of Participants in the Kiev Meeting on Issues of Normalisation of Relations between the Republic of Moldova and Transdniestria. 1999. Elérhető: www.osce.org/ moldova/42311?download=true (A letöltés dátuma: 2018. 11. 11.)

Karácsonyi, Dávid - Kocsis Károly - Kovály Katalin - Molnár József - Póti László: EastWest dichotomy and political conflict in Ukraine - Was Huntington right? Hungarian Geographical Bulletin, 63. (2014), 2. 99-134. DOI: https://doi.org/10.15201/ hungeobull.63.2.1

Kent, Neil - Vsevolod Samokhvalov: The Ukraine crisis: a Russian-European cold war? Journal of Intelligence and Terrorism Studies, (2016), 1. 1-11. DOI: https://doi. org/10.22261/SAXH48

Kühnhardt, Ludger: The Global Society and Its Enemies: Liberal Order Beyond the Third World War. Cham, Springer, 2017. DOI: https://doi.org/10.1007/978-3-319-55904-9

Kuzio, Taras (szerk.): Contemporary Ukraine - Dinamics of Post-Soviet Transformation. Michigan, M.E. Sharpe, 1998.

Matviyishyn, Yevhen - Tomasz Michalski: Language Differentiation of Ukraine's Population. Journal of Nationalism, Memory \& Language Politics, 11. (2017), 2. 181-197. DOI: https://doi.org/10.1515/jnmlp-2017-0008

Minsk II. Package of measures for the Implementation of the Minsk agreements. 2015. Elérhető: https://peacemaker.un.org/sites/peacemaker.un.org/files/UA_150212_MinskAgreement_en.pdf (A letöltés dátuma: 2019. 09. 26.)

Monzer, Frieder - Timo Ulrichs: Moldova - Mit Chisinau, ganz Bessarabien und Transdnestrien. Berlin, Trescher, 2016.

Odessa Agreement - Agreement on Confidence Measures and Development of Contacts between Republic of Moldova and Transdniestria. 1998. Elérhetö: www.osce.org/moldova/42310?download=true (A letöltés dátuma: 2018. 11. 10.)

Official Representation of the Pridnestrovian Moldavian Republic in Moscow. Ministry of Foreign Affairs of Pridenstrovian Moldavian Republic, 2019. Elérhető: http://mid. gospmr.org/en/yCy (A letöltés dátuma: 2020. 03. 18.)

O’Loughlin, John - Vladimir Kolossov - Andrei Tchepalyga: National Construction, Territorial Separatism, and Post-Soviet Geopolitics in the Transdniester Moldovan Republic. Post-Soviet Geography and Economics, 39. (1998), 6. 332-358. DOI: 10.1080/10889388.1998.10641081

Pełczyńska-Nałęcz, Katarzyna - Piotr Buras: The Minsk (dis)agreement and Europe's security order. Varsó, Stefan Bathory Foundation, 2017.

Peters, Tim B. - Anastasiia Shapkina: The Grand Stalemate of the Minsk Agreements. Sankt Augustin, Konrad-Adenauer-Stiftung, 2019.

Pittman, George R.: Why War? Indianapolis, Dog Ear Publishing, 2015.

Protocol on the Results of Consultations of the Trilateral Contact Group. 2014. Elérhető: https://mfa.gov.ua/en/news-feeds/foreign-offices-news/27596-protocolon-theresults-of-consultations-of-the-trilateral-contact-group-minsk-05092014 (A letöltés dátuma: 2019. 09. 26.)

Relations with the Republic of Moldova. NATO, 2018. Elérhető: www.nato.int/cps/en/ natohq/topics_49727.htm?selectedLocale=en (A letöltés dátuma: 2018. 11. 25.)

Relations with Ukraine. NATO, 2019. Elérhető: www.nato.int/cps/en/natolive/topics_ 37750.htm (A letöltés dátuma: 2019. 09. 27.) 
Report No. 13 by the CSCE Mission to Moldova. OSCE, 1993. Elérhető: www.osce.org/moldova/42307?download=true (A letöltés dátuma: 2018. 11. 05.)

Roper, D. Steven: Regionalism in Moldova: The Case of Transnistria and Gagauzia. In James Hughes - Gwendolyn Sasse (szerk.): Ethnicity and Territory in the Former Soviet Union: Regions in Conflict. London, Frank Cass, 2002. 101-122. DOI: https:// doi.org/10.4324/9780203045732-4

Sakwa, Richard: Háború a határon. Budapest, Európa, 2016.

Secretary-General, Alarmed at Escalation of Violence in Eastern Ukraine, Urges Adherence by Both Sides to Minsk Agreements, Including on Heavy Weapons Use. Statement of UN Secretary-General 17 August 2015. Elérhető: www.un.org/press/en/2015/sgsm17012. doc.htm (A letöltés dátuma: 2019. 11. 11.)

Secretary-General Expresses Concern over Killings of Prominent Persons in Ukraine. Statement of UN Secretary-General, April 17 2015. Elérhető: www.un.org/press/ en/2015/sgsm16671.doc.htm (A letöltés dátuma: 2019. 11. 11.)

Security Council Press Statement on Killing of Civilians at Public Transport Stop in City of Donetsk. Statement of UN Secretary-General, January 22 2015. Elérhető: www. un.org/press/en/2015/sc11749.doc.htm (A letöltés dátuma: 2019. 11. 11.)

Sobják, Anita: Is Transnistria the Next Crimea? PISM Bulletin, 49. (2014), 644. 1-2. 2.

Socor, Vladimir: Poroshenko Drafts, Yushchenko Launches A Plan For Transnistria. Eurasia Daily Monitor, 2. (2005), 82.

Special Monitoring Mission (SMM) to Ukraine: The Facts. OSCE, 2016. Elérhető: www.osce. org/ukraine-smm/116879?download=true (A letöltés dátuma: 2018. 09. 26.)

Statement. NATO, 1998. Elérhető: www.nato.int/cps/en/natohq/opinions_26126. htm?selectedLocale=en (A letöltés dátuma: 2018. 11. 25.)

Trilateral Statement by the Trilateral Contact Group. OSCE, 2014. Elérhető: www.osce.org/ home/123124 (A letöltés dátuma: 2019. 09. 26.)

The Moscow Memorandum - Memorandum on the Bases for Normalization of Relations Between the Republic of Moldova and Transdneistria. 1997. Elérhető: www.osce.org/moldova/42309?download=true (A letöltés dátuma: 2018. 11. 10.)

Troebst, Stefan: The "Transdniestrian Moldovan Republic": From Conflict-Driven StateBuilding to State-Driven Nation-Building. European Yearbook of Minority Issues, 2. (2002), 1. 5-30. DOI: https://doi.org/10.1163/221161103X00021

Troebst, Stefan: Kein spektakulärer Erfolg, aber Spannungen reduziert - Die OSZE in der Republik Moldova. Wissenschaft \& Frieden, (1997), 1.

United Nations Resolution adopted by the General Assembly on 27 March 2014 [without reference to a Main Committee (A/68/L.39 and Add.1)] 68/262. Territorial integrity of Ukraine. Elérhető: www.securitycouncilreport.org/atf/cf/\%7B65BFCF9B-6D27-4E9C8CD3-CF6E4FF96FF9\%7D/a_res_68_262.pdf (A letöltés dátuma: 2019. 09. 27.)

United Nations Resolution 2202 (2015) Adopted by the Security Council at its $7384^{\text {th }}$ meeting, on 17 February 2015. Elérhető: www.securitycouncilreport.org/atf/cf/\%7B65BFCF9B-6D27-4E9C-8CD3-CF6E4FF96FF9\%7D/s_res_2202.pdf (A letöltés dátuma: 2019. 09. 26.)

Vahl, Marius: The Europeanisation of the Transnistrian Conflict. CEPS Policy Brief No. 73, 2005. 
Vasa László: A moldovai gazdaság helyzete 2018-ban és jövőbeni kilátása. KKI Elemzések, (2018), 52. 3-5.

Waters, Trevor: Problems, Progress and Prospects in a Post-Soviet Borderland: The Republic of Moldova. IBRU Boundary and Security Bulletin, (1997), 1. 71-75.

Wilson, Andrew: Ukraine Crisis - What it means for the West. New Haven - London, Yale University Press, 2014.

Wood, Elisabeth A. - William Pomeranz - E. Wayne Merry - Maxim Trudolyubov: Roots of Russia's War in Ukraine. New York, Columbia University Press, 2015. DOI: https:// doi.org/10.7312/wood70453 